\title{
Red clover vein mosaic virus-A Novel Virus to New Zealand that is Widespread in Legumes
}

John Fletcher, New Zealand Institute for Plant \& Food Research, Christchurch, New Zealand; Joe Tang, Plant Health and Environment Laboratory, Ministry for Primary Industries, Auckland 1140, New Zealand; Arnaud Blouin, Plant \& Food Research, Auckland 1142, New Zealand; Lisa Ward, Plant Health and Environment Laboratory, Ministry for Primary Industries; Robin MacDiarmid, Plant \& Food Research, Auckland; and Heiko Ziebell, Julius Kuehn Institute, Institute for Epidemiology and Pathogen Diagnostics, 38104 Braunschweig, Germany

\begin{abstract}
Fletcher, J., Tang, J., Blouin, A., Ward, L., MacDiarmid, R., and Ziebell, H. 2016. Red clover vein mosaic virus-A novel virus to New Zealand that is widespread in legumes. Plant Dis. 100:890-895.

Red clover vein mosaic virus (RCVMV) is an important virus of leguminous crops that can cause devastating losses. During a routine survey of legumes conducted on the South Island of New Zealand, RCVMV was found in mixed infections in clover plants with Alfalfa mosaic virus and White clover mosaic virus. The full-length sequence of the New Zealand isolate RCVMV-NZ

from clover shared $96 \%$ nucleotide sequence identity with a chickpea isolate previously described from Washington (United States). Targeted surveys of pea, faba bean, and pasture crops showed that RCVMV-NZ is widespread on the South Island in New Zealand. This isolate is causing mild if any symptoms on experimental hosts and naturally infected plants.
\end{abstract}

Legumes and pasture plants are important agricultural crops for New Zealand, providing food for human consumption and fodder for cattle and sheep. Recent surveys have shown the widespread occurrence of different plant viruses affecting these crops (Guy 2014; Guy et al. 2013). More than 23 virus species have been found to have infected pasture grasses and legumes such as white, red, subterranean, and Caucasian clover and lucernes as well as other legumes (e.g., pea, Phaseolus bean, lentil, and broad bean) in New Zealand on both the South and North Islands (Denny and Guy 2009; Fletcher 1993; Guy 2014; Pearson et al. 2006). In the Canterbury region (South Island, the primary target of this report) pea, faba bean, and dwarf bean crops cover approximately 7,300 ha. Clover seed production covers 5,240 ha whereas lentil production is insignificant and chickpea is not grown. A further 1,136,000 ha are covered by mixed grass and legume pastures.

Red clover vein mosaic virus (RCVMV) was first reported from red clover in the United States by Osborn (1937) but has since been found in other legumes in many countries (Bos et al. 1972; Edwardson and Christie 1986, 1991; Hagedorn et al. 1959; Varma et al. 1970; Wetter et al. 1959). RCVMV belongs to the genus Carlavirus in the family Betaflexiviridae (Adams et al. 2004, 2012). Its flexuous particles contain a single-stranded (+)-sense RNA molecule with six open reading frames (Adams et al. 2004; Larsen et al. 2009). Thus far, only one complete genome sequence of an RCVMV chickpea isolate from Washington State, U.S.A., has been published (Larsen et al. 2009). RCVMV can cause vein mosaic or vein chlorosis as well as plant stunting depending on host species and virus isolate, although latent infections have also been reported (Bos et al. 1972; Graves and Hagedorn 1956; Hagedorn et al. 1959; Wetter et al. 1959). Economic losses caused by RCVMV infection have been up to $88 \%$ of the grain weight of moderately diseased pea (Khan and Singh 1997a) but yield losses in chickpea have been up to $100 \%$ depending on time of infection (Larsen and Miklas 2001).

Corresponding author: H. Ziebell; E-mail: heiko.ziebell@jki.bund.de

*The $\boldsymbol{e}$-Xtra logo stands for "electronic extra" and indicates that one supplementary figure is published online.

Accepted for publication 24 November 2015.

http://dx.doi.org/10.1094/PDIS-04-15-0465-RE

(C) 2016 The American Phytopathological Society
Several aphid species can transmit RCVMV in a nonpersistent manner; mechanical transmission and seed transmission have also been reported (Freeman 2007; Kraft et al. 1998; Osborn 1937; Sander 1959; Weber and Hampton 1980). Resistance to RCVMV in red clover has been reported (Hanson and Hagedorn 1961; Khan et al. 1978; Stuteville and Hansen 1964; Stuteville and Hanson 1964) but little information is available on resistant pea cultivars (Hagedorn 1968; Kraft et al. 1998).

Having accidently discovered RCVMV in a white clover (Trifolium repens $\mathrm{L}$.) sample during a routine survey of legumes for viruses, we aimed to characterize the biological and molecular properties of this virus. Because this was also the first report of RCVMV for New Zealand, we conducted surveys to investigate the incidence and distribution of RCVMV in the vicinity of the original finding (Dromore, MidCanterbury in the South Island). The surveys included a selection of locally grown annual legume crops (pea, broad bean, and dwarf bean) as well as mixed legume and grass pastures and clover weeds. The small area of lentil crops grown in Canterbury was not included in these surveys.

\section{Materials and Methods}

Annual crop surveys. With the cooperation of growers, seed merchants, and processors of broad bean (Vicia faba L.) and pea (Pisum sativum L.), 16 faba bean seed crops, 21 process and seed pea crops, as well as 12 process dwarf bean crops (Phaseolus vulgaris L.) were surveyed in Canterbury between 2011 and 2014. Based on the method used in past legume crop surveys (Fletcher 1993), 100 leaf samples were randomly collected in a "W" pattern for each crop. Leaves were stored at $4^{\circ} \mathrm{C}$ and serologically assayed for RCVMV and other legume viruses in groups of 10 leaves. Each bulked sample was tested by enzyme-linked immunosorbent assay (ELISA) for the following viruses: Alfalfa mosaic virus (AMV), Bean common mosaic virus, Bean yellow mosaic virus (BYMV), Broad bean stain virus, Broad bean true mosaic virus, Broad bean wilt virus 2, Broad bean mottle virus, Cucumber mosaic virus (CMV), Faba bean necrotic yellows virus, Pea seed-borne mosaic virus (PSbMV), Soybean dwarf virus (SbDV), Turnip yellows virus (TuYV; formerly known as Beet western yellows virus), and RCVMV. Doubleantibody sandwich (DAS) and triple-antibody sandwich ELISA were completed using kits supplied by Leibniz-Institute-Deutsche Sammlung von Mikroorganismen und Zellkulturen $\mathrm{GmbH}$ following the manufacturer's instructions for all legume viruses, apart from the DAS-ELISA detection of SbDV, which used antibodies produced at Plant \& Food Research (PFR), Lincoln, New Zealand. 
Perennial pasture and clover weed surveys. Two mixed pastures and two white clover pastures were sampled as described above and tested for RCVMV. A further 19 samples of weed clover from roadsides, farmland, and reserves around Canterbury were also collected and tested for RCVMV.

Indirect plate-trapped antigen (PTA)-ELISA. Indirect ELISA was completed at PFR, as described before (Fletcher 1993). For the detection of RCVMV, a polyclonal antiserum prepared at the Julius Kuehn Institute (JKI), Braunschweig, Germany was used at a dilution of 1:1,000 [ $\mathrm{vol} / \mathrm{vol}]$. A positive reaction was recorded when the mean optical density (OD) was greater than the mean of six negative controls plus three times the standard deviation. Virus incidence in surveyed crops was estimated using the method described by Fletcher (1993) and a table derived using the formula of Gibbs and Gower (1960). Survey results of other virus species detected are not reported here.

Direct DAS-ELISA. At JKI and the Plant Health and Environment Laboratory (PHEL), Auckland, New Zealand, direct DAS-ELISA was used according to Clark and Adams (1977). At JKI, the production of coating antibodies and conjugate was initially carried out with RCVMV-specific immunoglobulin $\mathrm{G}$ (IgG) derived from a German isolate of RCVMV; later, IgG derived from RCVMV-NZ was used (at a dilution of 1:1,000 [ $\mathrm{vol} / \mathrm{vol}]$ ).

At PHEL, DAS-ELISA was performed using an AC Diagnostics kit (Fayetteville, AR) following the manufacturer's instructions. Several RCVMV isolates from different host species and countries were used as positive controls. These included, in total, three isolates from $T$. repens and $V$. faba from New Zealand, one isolate from T. pratense L. from the American Type Culture Collection (ATCC, Manassas, VA), and one isolate from an unknown host species from AC Diagnostics. Healthy plants of $T$. repens and $V$. faba were also included as negative controls. A positive reaction was recorded when the mean OD was greater than three times the mean of the negative controls.

Electron microscopy. Transmission electron microscopy (TEM) was performed using a crude sap preparation, as described by Tang et al. (2013). Grids were examined using a JEOL JEM-1230 transmission electron microscope (JEOL Ltd., Tokyo).

Virus propagation and purification. The original white clover sample infected with RCVMV-NZ, AMV, and White clover mosaic virus (WClMV) was ground in buffer $(0.05 \mathrm{M}$ phosphate, $20 \mathrm{mM}$ sodium diethyldithiocarbamate (DIECA), $5 \mathrm{mM}$ sodium thioglycollate, $1 \mathrm{mM}$ sodium EDTA [pH 7.0], and $0.75 \%$ [wt/vol] activated charcoal) and mechanically inoculated onto virus-free Nicotiana benthamiana Domin., Chenopodium quinoa Willd., P. sativum, and $V$. faba 'Scirocco' plants in duplicate in order to find a suitable propagation host. The plants were kept under pest-free greenhouse conditions $\left(20^{\circ} \mathrm{C}\right.$ with additional light during the winter months for 16 h). Subsequently, C. quinoa plants were chosen for propagation of RCVMV because this plant is a nonhost plant for WCIMV (Brunt et al. 1996) but showed chlorotic lesions upon inoculation with RCVMV or AMV. Despite using excised local lesions for repeated inoculations of $C$. quinoa, separation of RCVMV and AMV was not successful using this assay. Therefore, it was decided to separate the two viruses by differential centrifugation during virus purification. Infected leaf material was frozen at $-20^{\circ} \mathrm{C}$ and stored until use. The material was mixed with three volumes of homogenate buffer $(0.01 \mathrm{M}$ sodium phosphate [pH 8.0], 0.01 M DIECA, and $0.5 \%$ [ $\mathrm{vol} / \mathrm{vol}]$ $\beta$-mercaptoethanol). A half-volume of chloroform was added and the solution was stirred for $5 \mathrm{~min}$. The solution was centrifuged for $10 \mathrm{~min}$ at $5,858 \times g$ (Sorvall GSA rotor). The upper supernatant was filtrated and the filtrate subject to centrifugation at approximately $115,000 \times g$ for $90 \mathrm{~min}$ (Beckmann 46Ti rotor). The pellets were resuspended in $100 \mathrm{ml}$ of borate buffer $(0.01 \mathrm{M}$ borium phosphate [ $\mathrm{pH} 8.3$ ] and $0.2 \mathrm{M}$ urea) and stored at $4{ }^{\circ} \mathrm{C}$ for $4 \mathrm{~h}$. The solution was centrifuged for $10 \mathrm{~min}$ at $5,200 \times g$ (Sorvall SA 600 rotor). The supernatant was mixed with $0.5 \%$ Triton X-100 and stirred at $4{ }^{\circ} \mathrm{C}$ overnight. The solution was carefully placed over sucrose cushions ( $25 \%$ sucrose in borate buffer) and centrifuged at $76,000 \times g$ for $2 \mathrm{~h}$. The pellets were resuspended in $30 \mathrm{ml}$ of borate buffer and centrifuged for $10 \mathrm{~min}$ at approximately $5,200 \times g$ (Sorvall SA 600 rotor). The supernatant was subject to cesium chloride gradient centrifugation $(400 \mathrm{mg} / \mathrm{ml})$ for $18 \mathrm{~h}$ at $120,000 \times g$ and $10^{\circ} \mathrm{C}$. The desired band containing virus particles was extracted and resuspended in borate buffer. The solution was centrifuged for $4 \mathrm{~h}$ and $25 \mathrm{~min}$ at 100,000 $\times g$ (Beckmann 70Ti rotor). The viral pellet was resuspended in $500 \mu$ l of borate buffer. Purity of the virus preparation was assessed by TEM.

Production of polyclonal antiserum. For the production of polyclonal antiserum, purified virus solution (virus at $400 \mu \mathrm{g} / \mathrm{ml}$ in $0.9 \%$ [wt/vol] sodium chloride) was mixed 1:1 with Freund's complete adjuvant and injected intramuscularly into one cross-bred rabbit. This procedure was repeated twice after 3 weeks, each time using Freund's incomplete adjuvant. Bleeding started 12 days after the last injection and was repeated every week for 2 months. IgG and conjugate production was carried out according to Clark and Adams (1977).

Reverse-transcription polymerase chain reaction for sequencing. Viral RNA was extracted from purified virions using the Qiagen RNeasy Plant Mini Kit (Qiagen, Hilden, Germany) following the manufacturer's instructions. The purified viral RNA or purified virions themselves were used as templates for a random reverse-transcription polymerase chain reaction (RT-PCR) approach, as described by Froussard (1992). First-strand cDNA synthesis was carried out using SuperScript III reverse transcription (Life Technologies, Darmstadt, Germany) according the manufacturer's instructions. Klenow polymerase (Life Technologies) was used for second-strand synthesis. The double-stranded cDNA was purified using the Zymo DNA clean kit (Zymo Research, Freiburg, Germany), according to the manufacturer's instructions. For PCR, $5.0 \mu \mathrm{l}$ of $10 \times$ buffer, $5.0 \mu \mathrm{l}$ of magnesium chloride $(25 \mathrm{mM}), 1.5 \mu \mathrm{l}$ of $\mathrm{UN}$ primer $(10 \mathrm{mM}), 5 \mathrm{U}$ of Axon Taq (Axon Labortechnik, Kaiserslautern, Germany), $8.0 \mu \mathrm{l}$ of purified doublestranded cDNA, and water to $50 \mu \mathrm{l}$ were added. PCR conditions were $1 \mathrm{~min}$ at $94^{\circ} \mathrm{C} ; 35$ cycles of $94^{\circ} \mathrm{C}$ for $20 \mathrm{~s}, 55^{\circ} \mathrm{C}$ for $30 \mathrm{~s}$, and $72^{\circ} \mathrm{C}$ for $90 \mathrm{~s}$; followed by a final extension step at $72^{\circ} \mathrm{C}$ for $10 \mathrm{~min}$. PCR products were subjected to gel electrophoresis in $1.5 \%$ [wt/vol] agarose gels. PCR products visualized on these gels were cut and purified using the Zymoclean Gel Recovery kit (Zymo Research), following the manufacturer's instructions. Purified PCR products were cloned using the Qiagen PCR Cloning Kit (Qiagen), following the manufacturer's instructions. Electrocompetent Escherichia coli DH5 $\alpha$ cells were transformed with the pDRIVE plasmids and selected on Luria-Bertani media plates containing ampicillin at $50 \mu \mathrm{g} / \mathrm{ml}$. Colonies were screened by blue-white selection and checked for appropriate inserts by colony PCR using the GoTaq Green master mix (Promega, Mannheim, Germany) and T7/SP6 primers. Colonies with desired inserts were propagated and plasmids purified using the Zymo Plasmid Prep Kit (Zymo Research). Sequencing was carried out by Eurofins Genomics (Ebersberg, Germany). Based on initial sequence information, specific RT-PCR primers were developed and used in standard PCR to amplify missing regions of the RCVMV genome. PCR products were sent directly to Eurofins Genomics for sequencing.

To obtain the $3^{\prime}$-end sequence, purified virus RNA was used for A-tailing with the A-Plus Poly (A) Polymerase Tailing Kit (Cellscript, Madison, WI), according to the manufacturer's instructions. The product was phenol/chloroform extracted and precipitated using one volume of ammonium acetate solution $(5 \mathrm{M})$ and resuspended in $20 \mu \mathrm{l}$ of sterile water. Reverse transcription of the tailed RNA was carried out with an oligo(d)T-primer Mix (Pappu et al. 1993) using SuperScript III reverse transcriptase. PCR was carried out using RCVMV-specific primer pairs or an oligo(d)T primer (cctcgggcagtccttttttttttttttt) in combination with an RCVMV-specific primer. The PCR products were sequenced directly.

To obtain the $5^{\prime}$-end sequence, cDNA using an RCVMV-specific primer located at positions 353 to 372 was produced and purified using the Nucleospin Gel and PCR clean-up kit (Macherey-Nagel, Düren, Germany). cDNA $(5 \mu \mathrm{l})$ was incubated with $4 \mu \mathrm{l}$ of TdTbuffer $(5 \times), 1 \mu l$ of terminal transferase (Promega, Mannheim, Germany), and $0.5 \mu \mathrm{l}$ of dATP $(100 \mu \mathrm{M})$ or dGTP $(100 \mu \mathrm{M})$ at $37^{\circ} \mathrm{C}$ for $60 \mathrm{~min}$. The reaction was stopped at $70^{\circ} \mathrm{C}$ for $10 \mathrm{~min}$. Standard PCR assays with tailed cDNAs were carried out using a second RCVMVspecific primer located at positions 297 to 316 and an oligo(d)T and oligo(d)C primer. Sequence assembly and subsequent analysis 
was carried out with the CLC Workbench (package 7, CLC bio; www.clcbio.com). The sequence was deposited in GenBank as accession number KR108251.

Development of standard RT-PCR protocol. RCVMV-specific primers RCVMV-5217F (5'-TGCACTGAATCGGATTATGA-3') and RCVMV-5728R (5'-GCATAAGACACTTCAATAGCAT-3') were designed based on the RNA-dependent RNA polymerase coding region of the only available RCVMV sequence in GenBank (accession number FJ685618) (Larsen et al. 2009), with a predicted amplicon of $512 \mathrm{bp}$. Total RNA was extracted using the InviMag Plant DNA mini Kit/KFml (Stratec Molecular GmbH, Berlin) and a Kingfisher milliliter semiautomated nucleic acid extraction instrument (Thermo Scientific, Waltham, MA), as per the manufacturers' instructions. One-step RT-PCR was carried out with the SuperScript III one-step RT-PCR system with Platinum Taq polymerase (Invitrogen, Life Technologies, Carlsbad, CA) using $2 \mu$ l of RNA template, $1 \mu \mathrm{l}$ each of $5 \mu \mathrm{M}$ forward and reverse primers, $1 \mu \mathrm{l}$ of a $10 \mathrm{mg} / \mathrm{ml}$ bovine serum albumen solution, $0.5 \mu$ l of SSIII RT/Platinum Taq mix, and $0.2 \mu l$ of RNasin Plus (Promega Corp., Madison, WI), and made up to a final volume of $20 \mu \mathrm{l}$ with nuclease-free water. RT-PCR was performed on a GeneAmp PCR system 9700 (Applied Biosystems, Waltham, MA) with the following cycling conditions: $94^{\circ} \mathrm{C}$ for $5 \mathrm{~min}$; then, 40 cycles of $94^{\circ} \mathrm{C}$ for $30 \mathrm{~s}, 54^{\circ} \mathrm{C}$ for $30 \mathrm{~s}$, and $72^{\circ} \mathrm{C}$ for $45 \mathrm{~s}$; followed by a final extension at $72^{\circ} \mathrm{C}$ for $5 \mathrm{~min}$. The PCR products were sequenced in both directions on an ABI 3130xl genetic analyzer (Applied Biosystems, Ecogene, Auckland, New Zealand). Sequences were edited and analyzed using Geneious 7.1.5 software (Biomatters Ltd., Auckland, New Zealand; http://www.geneious.com).

\section{Results}

Detection and purification of RCVMV, experimental host range, and TEM. During the annual legume survey of 2011, a symptomatic clover sample was detected in the Rakaia region of New Zealand's South Island (Fig. 1A). Analysis of the symptomatic white clover sample by ELISA and immunosorbent electron microscopy using antibodies from the JKI stock collection confirmed that the plant was infected with AMV and WCIMV (data not shown). The sample also contained RCVMV, which had not been found in New Zealand until then. In order to separate RCVMV from the other viruses, mechanical transmission to virus-free differential hosts such as C. quinoa was used. After several rounds of mechanical transmission, including the use of single lesions from C. quinoa, host plants still were infected by both AMV and RCVMV, as confirmed by ELISA (data not shown). Therefore, purification including cesium chloride density centrifugation was carried out to separate particles of AMV and RCVMV. RCVMV particles were successfully separated from AMV and used for further virus propagation and host range determination.

Using mechanical inoculations of diluted virus preparations (at approximately $100 \mu \mathrm{l} / \mathrm{ml}$ ), a range of virus-free experimental host plants was successfully inoculated in duplicate with RCVMV (Fig. 1B

Table 1. Red clover vein mosaic virus host and non-host plants as determined by mechanical inoculation using purified virions and detection by enzymelinked immunosorbent assay (ELISA) ${ }^{\mathrm{a}}$

\begin{tabular}{|c|c|c|}
\hline Plant species & Symptoms & ELISA reaction ${ }^{b}$ \\
\hline Chenopodium amaranticolor & Chlorotic lesions & +++ \\
\hline C. foliosum & No data & + \\
\hline C. murale & Chlorotic lesions & + \\
\hline C. quinoa & Chlorotic lesions & +++ \\
\hline Cicer arietinum & None & 0 \\
\hline Datura metel & None & 0 \\
\hline D. stramonium & None & 0 \\
\hline Gomphrena globosa & None & 0 \\
\hline Lens culinaris & None & 0 \\
\hline Medicago sativa & None & 0 \\
\hline M. trunculata & None & 0 \\
\hline Nicotiana benthamiana & None & 0 \\
\hline N. clevelandii & None & 0 \\
\hline N. debneyi & None & 0 \\
\hline N. glutinosa & None & 0 \\
\hline N. occidentalis $37 b$ & Mosaic & ++ \\
\hline N. occidentalis $P 1$ & Mosaic & +++ \\
\hline N. tabacum samsun-NN & None & 0 \\
\hline N. tabacum xanthii & None & 0 \\
\hline Physalis floridana & None & 0 \\
\hline Pisum sativum & None & +++ \\
\hline Trifolium incarnatum & Mosaic & +++ \\
\hline T. pratense & None & 0 \\
\hline T. resuspinatum & None & + \\
\hline Vicia faba & None & 0 \\
\hline
\end{tabular}

a Symptoms on Pisum sativum and Trifolium resuspinatum were very mild and indistinguishable from noninfected plants.

b Scale: $0=$ no reaction, $+=$ mild reaction, $++=$ intermediate reaction, and $+++=$ strong reaction.

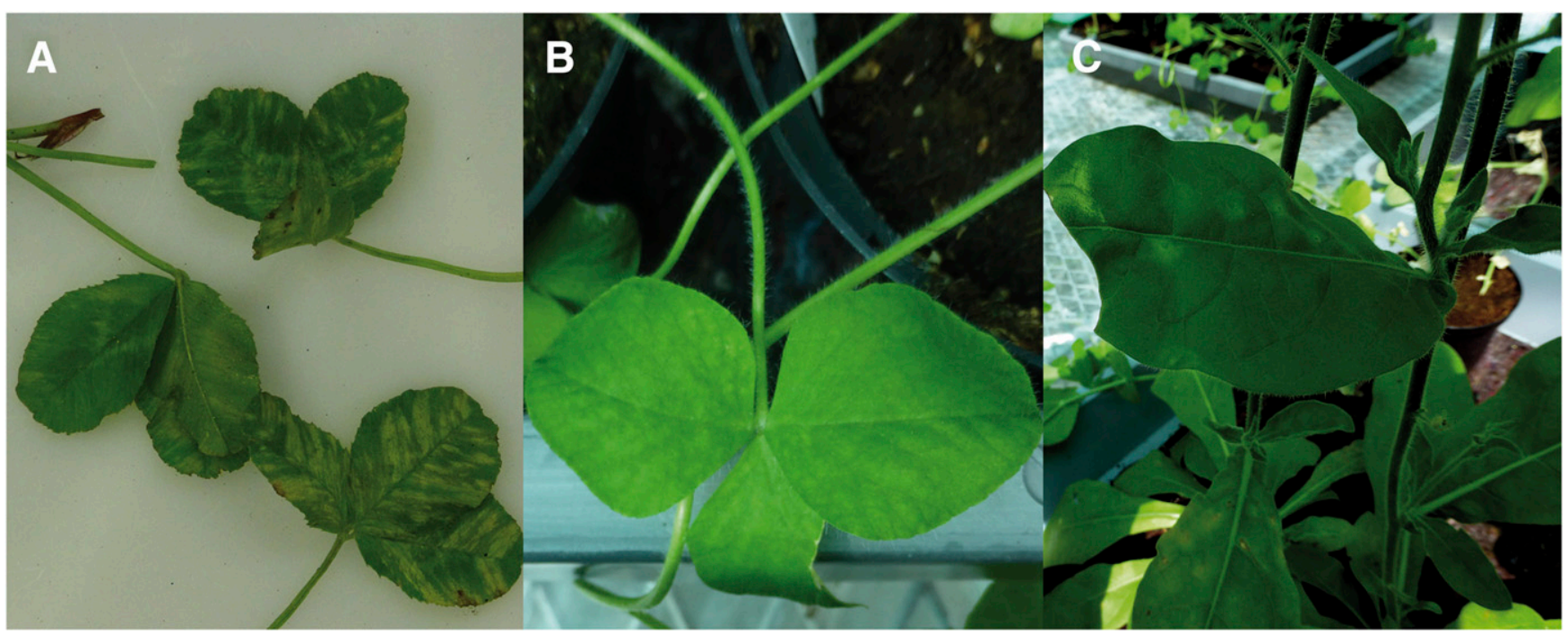

Fig. 1. Symptoms of Red clover vein mosaic virus (RCVMV, NZ isolate) on different host plants. A, Trifolium repens specimen in which RCVMV was detected for the first time in New Zealand in 2011. The plant displayed prominent symptoms of interveinal chlorosis and was subsequently found to be infected with RCVMV, Alfalfa mosaic virus (AMV), and White clover mosaic virus (WCIMV). The obvious symptoms induced by AMV and WCIMV infection might have masked the very mild RCVMV-specific symptoms. B, RCVMV symptoms on Trifolium incarnatum displaying mild mottling. C, RCVMV symptoms on Nicotiana occidentalis 37b showing chlorotic ring-spots. 
and C; Table 1). Susceptible host species included N. occidentalis Wheeler PI and 37b, C. quinoa, and C. murale L., as well as Trifolium spp. and garden pea (Table 1). Overall, symptoms were very mild (Fig. 1B and C; Table 1) and virus titers differed on different hosts (Table 1). Other leguminous experimental hosts such as faba bean or Medicago sativa L. and M. truncatula Gärtn. could not be mechanically infected under greenhouse conditions.

Slightly flexuous, filamentous particles approximately 650 by $12 \mathrm{~nm}$ in size (Supplementary Fig. S1) were observed from the original $T$. repens and inoculated $C$. quinoa plants. The particles were similar in morphology and dimensions to carlaviruses.

Antiserum production. Purified virions were used for the production of polyclonal antisera as outlined in the Materials and Methods section. Extraction of IgG and the production of conjugate were successfully used for routine detection of RCVMV in direct DAS-ELISA formats (JKI, experimental host range) and indirect DAS-ELISA formats (PFR, crop surveys in New Zealand).

Crop survey in New Zealand. After the first find of RCVMV on clover plants in New Zealand, virus surveys of legume and pasture crops included tests for RCVMV. This virus was found in pea, faba bean, green bean, $T$. pratense, $T$. repens, and mixed grass and clover pasture crops (Tables 2 to 4). Highest incidences in annual legume crops surveyed were in $V$. faba with up to $66 \%$ of process crops (0 to $20 \%$ range), $P$. sativum up to $36 \%$ of process crops (0 to $3.5 \%$ range), and $P$. vulgaris $41 \%$ of process crops ( 0 to $9 \%$ range). In Lincoln and mid-Canterbury, only clover pastures older than 3 to 5 years appeared infected with RCVMV (2 to $20 \%$ ), and $47 \%$ of the 32 individual clover weed plants surveyed were found infected with RCVMV.

Full sequence of RCVMV. Several attempts to obtain sequence information from the RCVMV-NZ isolate failed. This included the extraction of double-stranded RNA from infected plant material and subsequent random PCR (Froussard 1992) as well as immunocapture PCR using polyclonal trapping antibodies and a range of carlavirus-specific primers (Badge et al. 1996; Gaspar et al. 2008). Even the production of cDNA and subsequent PCR using oligo(d)T primers (Gaspar et al. 2008; Pappu et al. 1993) repeatedly failed to produce a PCR product. Random PCR (Froussard 1992) was only successful when viral RNA was purified directly from extracted virions. The amplicon fragments were cloned and sequenced. The sequences were used to design specific primers to amplify the sequence gaps using viral RNA in RT-PCR. The determination of

Table 2. Survey results on incidence of Red clover vein mosaic virus (RCVMV) in three annual legume vegetable crops from Canterbury, New Zealand, 2011 to 2014

\begin{tabular}{llccc}
\hline Plant species & $\begin{array}{c}\text { Crop } \\
\text { type }\end{array}$ & $\begin{array}{c}\text { Number } \\
\text { of crops }\end{array}$ & $\begin{array}{c}\text { Total RCVMV } \\
\text { incidence (\%) }\end{array}$ & $\begin{array}{c}\text { Range of } \\
\text { incidence (\%) }\end{array}$ \\
\hline Vicia faba & Seed & 10 & 60 & $0-20$ \\
& Process & 6 & 66 & $0-20$ \\
Pisum sativum & Seed & 7 & 28 & $0-3.5$ \\
\multirow{2}{*}{ Phaseolus vulgaris } & Process & 14 & 36 & $0-3.5$ \\
& Process & 12 & 41 & $0-9$ \\
\hline
\end{tabular}

Table 3. Survey results on incidence of Red clover vein mosaic virus (RCVMV) in pasture crops from Lincoln and mid-Canterbury, 2014

\begin{tabular}{ccccc}
\hline Type of crop & Location & $\begin{array}{c}\text { Number of } \\
\text { crops }\end{array}$ & $\begin{array}{c}\text { Age of crop } \\
\text { (in years) }\end{array}$ & $\begin{array}{c}\text { RCVMV } \\
\text { incidence } \\
(\%)\end{array}$ \\
\hline $\begin{array}{c}\text { White clover } \\
\text { seed crop } \\
\begin{array}{c}\text { Mixed clover } \\
\text { grass pasture }\end{array}\end{array}$ & $\begin{array}{c}\text { Boundary Rd } \\
\text { Lincoln } \\
\text { Lincoln } \\
\text { University }\end{array}$ & 1 & 1 & 0 \\
$\begin{array}{c}\text { Dairy } \\
\text { White clover } \\
\text { seed crop } \\
\text { Mixed clover } \\
\text { grass pasture }\end{array}$ & $\begin{array}{c}\text { Coe's Ford } \\
\text { Reserve }\end{array}$ & 1 & $20-30$ & 2 \\
\hline
\end{tabular}

the $3^{\prime}$-end sequence with oligo(d)T primer (Gaspar et al. 2008; Pappu et al. 1993) failed repeatedly (data not shown). The remaining sequence gaps at the 3 '-end finally was determined by A-tailing using the A-Plus Poly (A) Polymerase Tailing Kit. However, with this method, it is not possible to distinguish whether the poly (A)-tail sequences are of viral origin or were added during the procedure. The sequence was deposited at GenBank (accession number KR108251). BLAST analysis showed $96 \%$ identity on the nucleotide level to the Washington state isolate, the only published full-length sequence of RCVMV (Larsen et al. 2009).

Phylogenetic analyses. Due to the limited availability of RCVMV sequences in public databases, further analyses were conducted using PCR-amplified fragments of 512 bp in length that were consistently amplified from RNA extracts of different RCVMV-infected host species (including $T$. pratense, $T$. repens, $P$. sativum, and $V$. faba) from the North Island and South Island, New Zealand, and the United States. Phylogenetic analysis based on the obtained 512-bp nucleotide sequences (neighbor-joining algorithm using Kimura 80 distance measure and 1,000 bootstrap replicates) revealed that all New Zealand RCVMV isolates, regardless of the host species from which the isolate was derived, appeared to be monophyletic ( $94 \%$ bootstrap support; Fig. 2). The closest relative is the American chickpea isolate (Fig. 2) (Larsen et al. 2009). However, one isolate obtained from ATCC (PV-110) was quite distinct, sharing only about $75 \%$ nucleotide identity and $91 \%$ amino acid identity to the other isolates.

\section{Discussion}

This is the first report of RCVMV in New Zealand. The virus was purified for antiserum production and its genome fully sequenced (GenBank accession number KR108251). Although the occurrence of RCVMV in New Zealand had not yet been documented, subsequent surveys of legume and pasture crops showed that RCVMV is widespread in surveyed crop legumes. $V$. faba showed the highest infestation of around $60 \%$ of crops infected and up to $20 \%$ incidence in certain locations; in P. vulgaris, $40 \%$ crops were infected, with up to $9 \%$ incidence; and with $P$. sativum, around $30 \%$ crops were infected, with up to $3.5 \%$ incidence within a crop. This is surprising because attempts to mechanically infect $V$. faba or $T$. pratense under greenhouse conditions failed (Table 1). One can speculate that, under field conditions, effective transmission occurred through aphid vectors.

Table 4. Survey results on incidence of Red clover vein mosaic virus (RCVMV) in clover weed species from Mid-Canterbury (MC), Kaikoura (KA), South Canterbury (SC), and North Otago (NO), 2014

\begin{tabular}{|c|c|c|c|}
\hline Plant species & Location & Region & RCVMV positive \\
\hline Trifolium repens & $\begin{array}{l}\text { Dromore (original } \\
\text { isolation site of } \\
\text { RCVMV) }\end{array}$ & $\mathrm{MC}$ & $8 / 8$ \\
\hline T. repens & Foley Rd, Arowhenua & $\mathrm{SC}$ & $0 / 1$ \\
\hline T. pratense & Foley Rd, Arowhenua & $\mathrm{SC}$ & $0 / 1$ \\
\hline T. repens & $\begin{array}{l}\text { Pleasant Valley Rd, } \\
\text { St Andrews }\end{array}$ & $\mathrm{SC}$ & $1 / 1$ \\
\hline T. pratense & $\begin{array}{l}\text { Pleasant Valley Rd, } \\
\text { St Andrews }\end{array}$ & $\mathrm{SC}$ & $1 / 1$ \\
\hline T. repens & Springfield Rd, Totara & NO & $1 / 1$ \\
\hline T. pratense & Gerald St Lincoln & $\mathrm{MC}$ & $0 / 1$ \\
\hline T. repens & Gerald St, Lincoln & $\mathrm{MC}$ & $0 / 1$ \\
\hline T. pratense & Springs Rd, Lincoln & $\mathrm{MC}$ & $1 / 2$ \\
\hline T. repens & Springs Rd, Lincoln & $\mathrm{MC}$ & $2 / 2$ \\
\hline T. repens & $\begin{array}{l}\text { Birches Rd/Tancreds } \\
\text { Rd }\end{array}$ & MC & $0 / 1$ \\
\hline T. repens & Goulds Rd, Irwell & $\mathrm{MC}$ & $0 / 1$ \\
\hline T. repens & Rakaia & $\mathrm{MC}$ & $1 / 2$ \\
\hline T. pratense & Lake Pearson & MC & $0 / 1$ \\
\hline T. pratense & Lake Sarah & $\mathrm{MC}$ & $0 / 1$ \\
\hline T. pratense & Lake Hawdon & $\mathrm{MC}$ & $0 / 1$ \\
\hline T. repens & Lake Hawdon & MC & $0 / 1$ \\
\hline T. pratense & Quailburn & $\mathrm{SC}$ & $0 / 2$ \\
\hline T. pratense & Oaro & KA & $0 / 3$ \\
\hline
\end{tabular}


In the field, no visible symptoms were observed in any crop and the impact on yield was unclear but probably negligible, unless present with other viruses. This is in contrast to reports from the United States and India where RCVMV can cause severe crop losses on pea, chickpea, and lentils (Hagedorn and Walker 1949, 1954; Khan and Singh 1997a,b; Larsen and Miklas 2001; Larsen et al. 2009). ELISA analysis of host plants revealed the presence of numerous viruses, including AMV, CMV, BYMV, SbDV, TuYV, and PSbMV. Because RCVMV-induced symptoms are very mild (such as very mild systemic mottle on $T$. incarnatum L. or mild systemic chlorotic spots on $N$. occidentalis $37 \mathrm{~b}$; Fig. $1 \mathrm{~B}$ and C), these symptoms might have been masked by mixed infection with one or more of the other viruses that induce more severe symptoms.

In the four clover crops surveyed around Lincoln, RCVMV was only detected in crops over 20 years old and, even then, never exceeding 20\% incidence level. In the sampled clover weeds, apart from at the Dromore site where RCVMV was first observed, only $33 \%$ of plants were found to be infected. In the broad bean crop adjacent to the Dromore clover sample, $20 \%$ incidence of RCVMV was recorded.

From the survey of four clover crops, it seems likely that the spread of RCVMV may be quite slow in clover given its apparent absence in newly planted crops and low incidence in clover weeds from other regions. On the other hand, seasonal infection in annual legumes can reach up to $60 \%$ of crops, with up to $20 \%$ incidence, which implies high levels of infection from the legume aphids moving from clover weeds and pasture to these crops. Graves and Hagedorn (1956) and Freeman (2007) recorded Acyrthosiphon pisum (pea aphid), Aphis fabae, Cavariella aegopodii, C. theobaldi, Myzocallis onomidis, Myzus persicae, and Therioaphis maculata as vectors of RCVMV. Acyrthosiphon pisum, T. trifolii subsp. maculata, and M. persicae are common aphid species found in New Zealand clover pastures. Other potential virus vectors such as A. kondoi, Aphis craccivora, Aulacorthum solani, and M. ornatus are also found on clover and other legume crops in New Zealand. C. aegopodii is present in New Zealand but is not reported on clover or legumes (Ayong and Gordon 2010). Aphid transmission of RCVMV may be particularly important in broad bean because the crop in Canterbury is exposed to both late autumn and spring aphid flights. Pea and dwarf bean crops are only exposed to spring aphid flights. Seed transmission of RCVMV has been reported in red clover, broad bean, and field pea (Freeman 2007), which may also contribute to the spread of RCVMV in New Zealand.

Although RCVMV has been reported to cause leaf chlorosis and yield loss in susceptible cultivars of red clover (Khan et al. 1978), the effect of RCVMV on clover is not very clear. That is because other viruses (e.g., AMV, BYMV, Clover yellow vein virus, or WCIMV, all present in New Zealand) also naturally infect clover and are often found in mixed infections (Alconero et al. 1986; Sherwood 1997). For example, Gibbs et al. (1966) found that white clover plants were symptomless when infected with RCVMV alone unless also infected with Clover yellow vein virus. RCVMV has also been reported to cause pea stunt diseases with severe reduction of growth and yield in some pea cultivars in India (Khan and Singh 1997a,b). However, our investigations show that RCVMV-NZ causes only very mild symptoms in pea and other host plants (Fig. 1; Table 1). RCVMV is likely to be established and widespread in New Zealand. This conclusion is based on its seed transmissibility, and the fact that most of its reported aphid vectors are present in New Zealand and common on reported RCVMV host plants, especially the pea aphid. Furthermore, the perennial cultivated or wild legume species can play a role as a whole-year reservoir for RCVMV to infect other crops in new seasons.

Because New Zealand runs one of the strictest plant health and quarantine regimes in the world, one can only speculate about the introduction of RCVMV to New Zealand. The nucleotide sequence of RCVMV-NZ differs by only $4 \%$ from the isolate from Washington State; therefore, one could assume the same origin of the two isolates. Because natural transmission of the virus by insect vectors over the distance from Washington State to New Zealand is unlikely, it is possible that RCVMV was introduced unknowingly by humans, most likely by imported seed or plant material. As has been shown, RCVMV causes only very mild symptoms on certain hosts (pea and clover; Fig. 1B and C); therefore, it is reasonable to expect that infected plant material might have accidentally been imported but not detected.

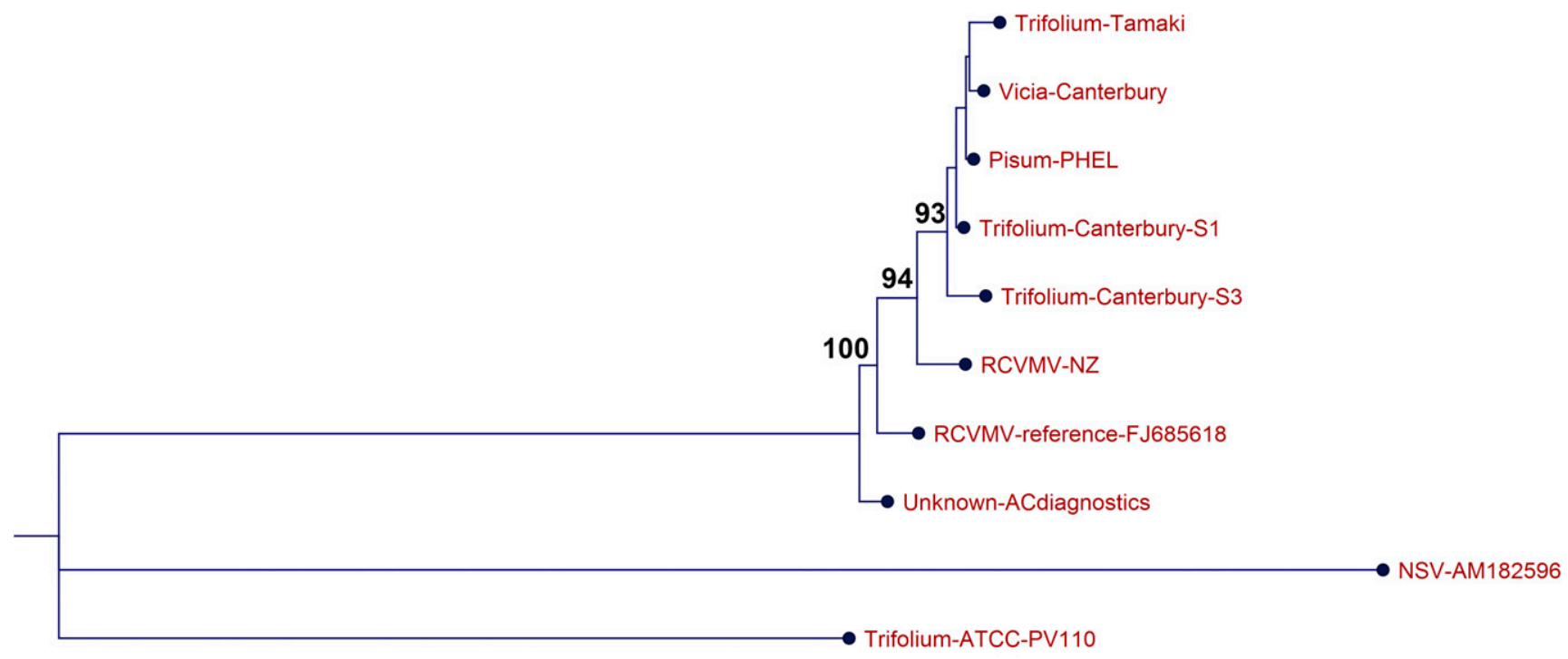

0,110

Fig. 2. Phylogenetic relationship of Red clover vein mosaic virus (RCVMV) isolates based on approximately 520-bp nucleotide sequences generated by primers RCVMV5217F/5728R and from GenBank (the reference sequence). The tree was created using neighbor-joining algorithm with Kimura 80 distance measure and 1,000 bootstrap replicates. The tree was rooted with Narcissus symptomless virus (NSV)-AM182596 and Trifolium-American Type Culture Collection (ATCC)-PV110. Only bootstrap values above $70 \%$ are indicated. Interestingly, the isolate obtained from ATCC is distinct from others; that is, it shares only approximately $75 \%$ nucleotide $(91 \%$ on the amino acid sequence) identity to other isolates, while the latter have $>98 \%$ nucleotide identity to each other. 
Attempts to amplify RNA extracted from purified RCVMV virions using oligo(d)T primers for cDNA production and generic carlavirus primer for PCR repeatedly failed in both the New Zealand and German laboratories. Sequencing of the $3^{\prime}$ end was finally achieved by A-tailing of the $3^{\prime}$ end and RT-PCR using oligo(d)T primers; however, this did not allow us to distinguish whether the A-tail was of viral origin or was artificially added. It might be possible that RCVMV-NZ does not have a poly-A tail as described for other carlaviruses or that the tail is truncated in such a way that cDNA production using oligo(d)T primers fails. The biological relevance of an RCVMV isolate without a poly-A tail remains to be elucidated.

\section{Acknowledgments}

Parts of this work were funded by a bilateral cooperation grant by the Federal Office of Agriculture and Food (Germany) and the Royal Society of New Zealand. We thank A. Sieg-Müller and P. Lüddecke for excellent technical support; and W. Maier, K. Richert-Pöggeler, and W. Menzel for discussion.

\section{Literature Cited}

Adams, M. J., Antoniw, J. F., Bar-Joseph, M., Brunt, A. A., Candresse, T., Foster, G. D., Martelli, G. P., Milne, R. G., Zavriev, S. K., and Fauquet, C. M. 2004. The new plant virus family Flexiviridae and assessment of molecular criteria for species demarcation. Arch. Virol. 149:1045-1060.

Adams, M. J., Candresse, T., Hammond, J., Kreuze, J. F., Martelli, G. P., Namba, S., Pearson, M. N., Ryu, K. H., Saldarelli, P., and Yoshikawa, N. 2012. Family Betaflexiviridae. Pages 920-941 in: Virus Taxonomy. Classification and Nomenclature of Viruses. Ninth Report of the International Committee on Taxonomy of Viruses. A. M. Q. King, M. J. Adams, E. B. Carstens, and E. J. Lefkowitz, eds. Elsevier Academic Press, Amsterdam.

Alconero, R., Fiori, B., and Sherring, W. 1986. Relationships of virus-infections to field performance of six clover species. Plant Dis. 70:119-121.

Ayong, S. T., and Gordon, D. P. 2010. Phylum Arthoropoda. Pages 401-402 in: New Zealand Inventory of Biodiversity. D. P. Gordon, ed. Canterbury University Press, Christchurch, New Zealand.

Badge, J., Brunt, A., Carson, R., Dagless, E., Karamagioli, M., Phillips, S., Seal, S., Turner, R., and Foster, G. D. 1996. A carlavirus-specific PCR primer and partial nucleotide sequence provides further evidence for the recognition of cowpea mild mottle virus as a whitefly-transmitted carlavirus. Eur. J. Plant Pathol. 102:305-310.

Bos, L., Maat, D. Z., and Markov, M. 1972. A biologically highly deviating strain of red clover vein mosaic virus, usually latent in pea (Pisum sativum), and its differentiation from pea streak virus. Neth. J. Plant Pathol. 78:125-152.

Brunt, A., Crabtree, K., Dallwitz, M., Gibbs, A., and Watson, L. 1996. Viruses of Plants. Descriptions and Lists from the VIDE Database. University Press, Cambridge.

Clark, M. F., and Adams, A. N. 1977. Characteristics of the microplate method of enzyme-linked immunosorbent assay for the detection of plant viruses. J. Gen. Virol. 34:475-483.

Denny, B. L., and Guy, P. L. 2009. Incidence and spread of viruses in white-clover pastures of the South Island, New Zealand. Australas. Plant Pathol. 38:270-276.

Edwardson, J. R., and Christie, R. G. 1986. Viruses Infecting Forage Legumes, Volume I. Agricultural Experiment Stations, Institute of Food and Agricultural Sciences, University of Florida, Gainesville.

Edwardson, J. R., and Christie, R. G. 1991. CRC Handbook of Viruses Infecting Legumes. CRC Press, Boca Raton, FL.

Fletcher, J. D. 1993. Surveys of virus diseases in pea, lentil, dwarf and broad bean crops in South Island, New-Zealand. N. Z. J. Crop Hortic. 21:45-52.

Freeman, A. 2007. Red clover vein mosaic carlavirus. National Diagnostic Protocol. Department of Primary Industries, Primary Industries Research Victoria, Knoxfield, Victoria, Australia.

Froussard, P. 1992. A random-PCR method (rPCR) to construct whole cDNA library from low amounts of RNA. Nucleic Acids Res. 20:2900.
Gaspar, J. O., Belintani, P., Almeida, A. M. R., and Kitajima, E. W. 2008. A degenerate primer allows amplification of part of the 3 -terminus of three distinct carlavirus species. J. Virol. Methods 148:283-285.

Gibbs, A. J., and Gower, J. C. 1960. The use of a multiple-transfer method in plant virus transmission studies-Some statistical points arising in the analysis of results. Ann. Appl. Biol. 48:75-83.

Gibbs, A. J., Varma, A., and Woods, R. D. 1966. Viruses occurring in white clover (Trifolium repens L) from permanent pastures in Britain. Ann. Appl. Biol. 58:231-240.

Graves, C. H., and Hagedorn, D. J. 1956. The red clover vein-mosaic virus in Wisconsin. Phytopathology 46:257-260.

Guy, P. L. 2014. Viruses of New Zealand pasture grasses and legumes: A review. Crop Pasture Sci. 65:841-853.

Guy, P. L., Gerard, P. J., and Wilson, D. J. 2013. Incidence of viruses in white clover on the North Island of New Zealand. Australas. Plant Pathol. 42:639-642.

Hagedorn, D. J. 1968. Disease reaction to Pisum sativum plant introductions to three legume viruses. Plant Dis. Rep. 52:160-162.

Hagedorn, D. J., Bos, L., and van der Want, J. P. H. 1959. The red clover veinmosaic virus in the Netherlands. Tijdschr. Planteziekten 65:13-23.

Hagedorn, D. J., and Walker, J. C. 1949. Wisconsin pea stunt, a newly described disease. J. Agric. Res. 78:617-626.

Hagedorn, D. J., and Walker, J. C. 1954. Virus disease of canning peas in Wisconsin. Res. Bull. Wisc. Agric. Exp. Stn. 185:3-31.

Hanson, E. W., and Hagedorn, D. J. 1961. Viruses of red clover in Wisconsin. Agron. J. 53:63-67.

Khan, A. T., and Singh, R. N. 1997a. Effect of pea stunt disease on flowering, podding, grain setting and yield. Indian Phytopathol. 50:282-284.

Khan, A. T., and Singh, R. N. 1997b. Effect of pea stunt disease on shoot development in field pea. Indian Phytopathol. 50:285-289.

Khan, M. A., Maxwell, D. P., and Smith, R. R. 1978. Inheritance of resistance to red clover vein mosaic virus in red clover. Phytopathology 68:1084-1086.

Kraft, J. M., Larsen, R. C., and Inglis, D. A. 1998. Diseases of pea. Pages 325-370 in: The Pathology of Food and Pasture Legumes. D. J. Allen and J. M. Lenné, eds. CAB International, Wallingford, UK

Larsen, R. C., and Miklas, P. N. 2001. Effect of red clover vein mosaic carlavirus infection on seed production and biomass yield in chickpea. (Abstr.) Phytopathology 91:S186.

Larsen, R. C., Wyatt, S. D., and Druffel, K. L. 2009. The complete nucleotide sequence and genome organization of red clover vein mosaic virus (genus Carlavirus). Arch. Virol. 154:891-894

Osborn, H. T. 1937. Vein-mosaic virus of red clover. Phytopathology 27: 1051-1058

Pappu, S. S., Brand, R., Pappu, H. R., Rybicki, E. P., Gough, K. H., Frenkel, M. J., and Niblett, C. L. 1993. A polymerase chain reaction method adapted for selective amplification and cloning of $3^{\prime}$ sequences of potyviral genomes-Application to dasheen mosaic virus. J. Virol. Methods 41:9-20.

Pearson, M. N., Clover, G. R. G., Guy, P. L., Fletcher, J. D., and Beever, R. E. 2006. A review of the plant virus, viroid and mollicute records for New Zealand. Australas. Plant Pathol. 35:217-252.

Sander, E. 1959. Biological properties of red clover vein mosaic virus Phytopathology 49:748-754.

Sherwood, R. T. 1997. Viruses of white clover in pastures of Pennsylvania, New York, and Vermont. Plant Dis. 81:817-820.

Stuteville, D. L., and Hansen, J. N. 1964. Resistance to viruses in red clover. Crop Sci. 4:631-635.

Stuteville, D. L., and Hanson, E. W. 1964. Resistance in red clover to five viruses. (Abstr.) Phytopathology 54:909.

Tang, J., Ward, L. I., and Clover, G. R. G. 2013. The diversity of Strawberry latent ringspot virus in New Zealand. Plant Dis. 97:662-667.

Varma, A., Gibbs, A. J., and Woods, R. D. 1970. A comparative study of red clover vein mosaic virus and some other plant viruses. J. Gen. Virol. 8: 21-32.

Weber, K. A., and Hampton, R. O. 1980. Transmission of two purified carlaviruses by the pea aphid. Phytopathology 70:631-633.

Wetter, C., Quantz, L., and Brandes, J. 1959. Verwandtschaft zwischen dem Stauchevirus der Erbse und dem Rotkleeadernmosaik-virus (red clover vein mosaic virus). Phytopathol. Z. 35:201-204. 